\title{
SEMIOTIC IN INTERPRETING THE TEXT OF WOMEN'S ROLE INDONESIAN HORROR FILM IN "SETAN JAMU GENDONG"
}

\author{
Rr. Astri Indriana Octavita and Yulia Sofiani Zaimar* \\ English Education Department, Indraprasta PGRI University Jakarta \\ Received on 30 September 2018 / Approved on 15 October 2018
}

\begin{abstract}
This research applies an analysis of a woman character in Indonesian horror film, through deeply exploration of Setan Jamu Gendong movie. This horror film, that is concerned with female sexuality. Jamu seller character in Setan Jати Gendong movie would be chosen to be the subject of this academic research, usually comparing their features with those of the stereotype. The data that is taken, show the jamu seller should be considered as protagonist characters. Nevertheless, she could express multiple functions. While this is a broad and concentrate on area of the research, work in it has been shaped by a pronounced emphasis upon semiotic and feminist theory, which the researchers think, has limited the field in analyzing. In defining these diverse constructs, the researchers expand this focus sexuality by drawing from critical theories of semiology to provide the details of the way that taken-for-granted ideas about normative female sexuality are articulated, and stereotyping in popular culture. Over the research, it would show, how these paradigms serve to constrain and simplify broader cultural conceptualizations of female semiotically sexuality, placed them in second gender, At the outset of the research, the researchers had hoped to find out, that the horror genre in Indonesia was a place in which alternative modes of being and subordination could be explored and considered.
\end{abstract}

Keywords: women, јати, semiotic, gender, stereotype

\begin{abstract}
ABSTRAK
Penelitian ini mengemukakan tentang posisi perempuan dalam salah satu film horor Indonesia, yang berjudul Setan Jamu Gendong. Hal yang membuat penellit tertarik, bahwa film ini mengedepankan sensualitas tokoh utama perempuan, yang berprofesi sebagai tukang jamu gendong keliling..Tukang jamu tersebut dipilih sebagai obyek utama dalam penelitian ini, karena ia membuat stereotipe perempuan sebagai gender kedua dalam masyarakat. Penjual jamu tersebut berperan sebagai protagonis, yang memerankan beberapa peran, baik itu antagonis maupun protagonis. Dalam penelitian ini, peneliti bermaksud menggunakan teori semiotik dan gender sebagai mata pisau, guna membedah permasalahan posisi perempuan dalam film Setan Jamu Gendong ini. Peneliti memutuskan untuk memilih kedua teori tersebut, dikarenakan penelliti bermaksud ingin melihat film tersebut secara detail, bagaimana bahasa yang digunakan dalam film tersebut dapat dikaitkan dengan permasalahan posisi perempuan dalam masyarakat Indonesia pada umumnya dan dalam film tersebut pada khususnya. Hal ini, dikarenakan, permasalahan sexualitas adalah suatu permasalahan yang pelik dalam konstruksi norma dalam masyarakat Indonesia, yang dapat menempatkan kaum perempuan sebagai gender kedua.
\end{abstract}

Kata Kunci: perempuan, jaтu, semiotika, gender, stereotipe

\section{INTRODUCTION}

In general, every media culture will produce images, sounds, and glasses as the fabric of everyday life. Especially, films can help people understand what is happening in a film that has an influence on human life. Every human being has five senses, an instinctive need or feeling as one of those needs. In filling the human mind someone is watching any movie. Film is a form of media that can influence one's view of something. As a new

\footnotetext{
*Author(s) Correspondence:

E-mail:mrs.astriindriana@gmail.com,oleel27@gmail.com
} 
medium, film can bring us closer to heaven or closer to hell, because the effect depends on the wearer, people can be positive, negative, constructive, or even destructive. Film can be a visual language for people. People who are treated to scene scenes, which contain various meanings in the visualization made by the producer. Visual sensation in watt film is the most important thing, which means that the eye becomes one of the five senses, exploring the meaning in the film.

This research would aim to analyze the function of characters in a sample of narrative Indonesian horror films. Many of those characters have appeared, since the beginning of cinema and have long been shown by the literature, in creating a powerful stereotype in the cultural mind, that inadequately real characters and the work they do. Moreover, this research aims to carry out semiotic analysis on two selection of visuals Indonesian Horror movie as texts. The analysis will focus on examining the iconic representation of women in Indonesian media, and the depicted, in which they have been portrayed. Before going through on an outline of the theory involved in performing analysis, the role of women in Indonesia will be explored, as the basis of contextualizing this research. This research takes one of Indonesian horror movie, entitled Setan Jamu Gendong, whose cast is Julia Perez (late) and Dimas Aditya. This movie was released in 2009, written by Koya Pagayo.

Indonesian horror film is a very fantastic genre, dedicated exclusively to the audience. The best way to redisplay this genre is to consider what the devil is like and where they came from. Satan's representation in Indonesian horror films is largely determined by his physical appearance, and what causes him to become a demon. In Indonesian horror films, there are many types of demons, which are explored. An important aspect that makes researchers interact in the ghost is the body of a woman. There is only Pocong and Setan Jeruk Purut, which are considered as male ghosts in Indonesian films. Indeed, this gender representation has been regarded as the subject of years of debate. In understanding this construction problem, it is important for researchers to examine the visual semiotic representation of women in the Indonesian horror genre.

Since the New Order, many Indonesian producers have produced horror films, with a woman as a ghost center actress. For example, the films played by Suzanna. By seeing this, horrified, women are always interested in being victims. In the long run, women who are sexually fond of horror films tend to die first as punishment for sexual harassment. Facing this problem, according to Dallery (1989):

"This female positionality stands in contrast to the «standards of objectivity, rationality, and universality, [that] require the exclusion of the feminine, the bodily, the unconscious. Indeed, the logical ordering of reality into hierarchies, dualisms, and binary systems presupposes a prior gender dichotomy of man / woman. Not only has women's voice or experience been excluded from the subject matter of western knowledge, but even when the discourse is 'about' women, or women are the speaking subjects, (it) they still speak(s) according to phallocratic codes..."

By looking at this statement, the researcher might formulate the purpose of this research, by questioning: first, how can one interpret the body of semiotic women in Setan Jamu Gendong? The second question will go to; how can the female seller of jamu carry in the film serve the position of Indonesian women? By doing this research, the researchers will show that how women are increasingly being used as accessories for entertaining. There is a serious shortage of popular Indonesian horror films that reflect women being men outside the world of men. This interpretation directs researchers to study genres that use formulas to build words used by women in films. As the scope of this research, researchers aim to examine the female body and stereotypes in the film Setan Jamu Gendong. This representation is formed in all verbal and nonverbal signs associated with this film, considered as text.

\footnotetext{
*Author(s) Correspondence:

E-mail:mrs.astriindriana@gmail.com,oleel27@gmail.com
} 


\section{THEORETICAL REVIEW}

Many studies have documented the presence of stereotypes of women in Indonesian horror films, which is the first horror film. This research will focus on Indonesian horror films, Setan Jamu Gendong, thinking they behave, or they must behave, would researchers semiotically noted that the most common theme in films was the subordination of women. In this study, researchers will apply the semiotic theory, connecting the position of women in the horror film Setan Jamu Gendong.

Semiotics generally refers to meaning, that how representation, taken from language, images, objects, produces meaning or process, where the interpreter means meaning. For visual images in general cultural languages, semiotics will provide a broader interpretation, the study of symbolism. In addition, the use of semiotic analysis makes concepts such as naturalism and realism, which can objectively devote something. Ferdinand de Saussure (1857-1913) had created semiology at the beginning of the $20^{\text {th }}$ century, applying it as the study of the role of signs as part of life. Real semiotics may be related to structuralism, which also has a realistic mechanism in Saussure's thinking.

Instead, this research does not mean using Saussure theory, but the theory, derived from Roland Barthes, who is known as a student of Ferdinand de Saussure. The work of Roland Barthes shows important aspects of semiotics that will be discussed. In understanding its theories, researchers will say that Barthes, like the Saussure point to analyze how meaning can connect to images is not the natural outcome of what other researchers see, that images may not stand alone, and become universal in what people can think.

According to Zaimar (2008, p. 5), "Barthes's theory of using the concept of dichotomic language is the main concept in Saussure, and of course is a great literary work, in relation to previous linguistics which aims to find out the causes of change. Semiotic theory may be simple. Barthes, followed by the main semiologists, thinks that linguistics only forms part of the general science of signs." This statement was affirmed by Barthes himself, which implies that: "Barthesian semiotics is more interested in" the code used by the narrator and reader in the entire narrative itself, rather than the narrator's actions or motives or the effect of his actions on the reader."

Speaking of signs, Barthes divides into markers and markers. In linguistics, the form of the sign does not cause a signifying relationship. Roland Barthes in his book Elements of Semiology explains that "the words signify and signify, however, the sign remains unclear, because it tends to be identified with markers only, which Saussure wants to avoid as much as possible; after hesitation between several and the same, forms and ideas, images and concepts, Saussure settled on the signifier and signifies the unity that forms the sign. This is the most important proposition, which must always be remembered, because there is a tendency to interpret the sign as a marker, while this is a two-sided entity like Janus."

Based on the quote above, the sign function contains objects to double progress, which must be separated. The sign function can be covered with meaning. Because Roland Barthes has followed the Saussure sign model, which focuses on denotation at the expense of connotation to offer an important point of view. Regarding this matter, according to Roland Barthes (1972), "connotations and denotations are often described in terms of the level of representation or level of meaning. $\mathrm{He}$ also implies that the idea that there are different marking orders". In accordance with the quote, researchers can prove that the text will always carry massage, and in linguistic messages, the text consists of denotations and connotations

Speaking of meaning, the basic meaning of the signified has given a concoction, which is primarily centered on the level of reality, however, in emphasizing the fact that what is signified is not something. However, a kind of representation of the object itself, and it also will not explain its form. Looks sharp, the sign is a kind of semantics.

\footnotetext{
*Author(s) Correspondence:

E-mail:mrs.astriindriana@gmail.com,oleel27@gmail.com
} 
Explaining this, Barthes (1967), shows that "the importance of both markers and markers is the relationship between them; in this relationship the meaning was created [...] That the words that if this conflict is maintained, the meaning is unambiguous"

By exposing this film, the researchers saw that this film was semiotically about gender stereotypes. By researching this film, the searchers will also apply feminist theory, coming Julia Kristeva. The reason why the researchers chose him is the theory, because we found him in semiotic terms about the position of women. Kristeva makes symbolic and semiotic meanings, connecting linguistic terms. This subordination of women's position, explained in Kristeva's words, "realization of secession and the world is what produces language" (Kristeva, 1986). Based on that, in his eyes, men or women have their own language, which places them in different genders.

\section{RESEARCH METHOD}

Speaking of methods, this study uses interpretative qualitative-descriptive. The research method used in this study is the qualitative descriptive research, so it obtains data from Youtube that is valid and in accordance with the needs being researched. According to Given (2008), "the best qualitative method is to examine many of the why and how questions of human experience, in making decisions such as (not only what, where, when, or" who; and has a strong foundation in the field of sociology to understand government and social programs"

Based on his explanation, research on literary or cultural work is needed, where risk involves creative ways, given better recognition in other qualitative research in the future. In qualitative research, researchers can use stimulus texts, such as pictures, films, and so on.

\section{RESULT AND DISCUSSION}

By giving film elements have many aspects, in this study will focus on visualizing relationships that look at the body which then correlates with the audience. This research will examine the exact relationship of the body that looks at one in a movie with a horror theme. Researchers will focus on the formulation of the problem of how to look at the object of research, that women in the film Setan Jamu Gendong are identified as a synchronic approach to achieving women's visual substance. Indonesian horror women and men figures, Setan Jamu Gendong has a big role, because every performance character is always positioned as the character maker represented by the conflict.

The film Setan Jamu Gendong represents people from indigenous Indonesian cultural backgrounds, especially for Javanese people. Setan Jamu Gendong, whose main character Julia Perez as a jamu seller is a horror film that has the pinnacle of success in the millennium era. Generally, the elements that become the building blocks of films are the forms of visual elements and sound (horror sound). This film has a totality of meaning, taken from all scenes. Forming elements is something that cannot be separated, but in this study that will focus on the costumes and behavior of the main female characters. The story begins, when a woman, named Sri moves to Jakarta to look for work, after her husband dies. He left Sri and her son without inheriting any material support. In Jakarta, Sri joined the jати seller group. Unfortunately, one day she was a victim of a gang, who raped and killed her one night hiding his body to hide. After she died, she became a ghost to change this gang.

Discussing this film, Setan Jamu Gendong is not like other ghosts. It finally shows that Indonesian horror films have succeeded, creating feelings for change. By seeing ghosts, it is not a kind of Indonesian Satan, like pocong, or kuntilanak, or some satanic spirits. On the contrary, the audience gets enthusiasm, by a young woman, who is a jamu seller. The way she haunts all the dark roads, resonates crying ... "Herbalism ne ... mas... jamu ..." These words can be analyzed as symbols of the strength of women, who sell

\footnotetext{
*Author(s) Correspondence:

E-mail:mrs.astriindriana@gmail.com,oleel27@gmail.com
} 
herbs. This is related to what Kristeva (1986) explained:

"[Any] text (and any subject) is polyvalent, polylogical, plural, unfixed [...] The subject is always in process in that $\mathrm{s} / \mathrm{he}$ is not fixed, but always developing. But also, the subject is always in process because $s /$ he is always on trial, being tested against the various contexts in which s/he has his/her being."

Talking about the image of women in most Indonesian horror films has a subordinate image. By looking deeply at the echo of "Ne herbal ... mas ... jaатиии ..." It could be that research, gender roles are widely used in horror films to determine the role of one gender in relation to others, and some topics argue that Indonesian horror films are obsessed with gender subordination. Indonesian horror films focus on gender relations, because people define themselves based on gender. The effects of horror films on body images have been examined by researchers, ranging from semiologists to knowing massage behind echoes.

When people hear the word jamu, they must be reminded of traditional medicine, especially from Java. So, in semiology, it can be considered a marker. The reason why it happens is when people hear the word jamu, their brain will be semantically connected to traditional medicine (to denotation). However, when the words come from young beautiful women, who sell, it will bring new interpretation, instead. Indeed, people today are presented, that the media and body image have a deep connection. In semiology, this problem is called expansion of meaning, which carries myth. This is similar to the mythical theory of Roland Barthes. According to Roland Barthes (cited in Kristeva, 1986):

"A myth is the most appropriate means to deliver the ideological inversion so called in our nature of society. It is a reality that a myth provided to the world. The myth gives back inartificial images of reality to the world. And the myth with the historical proper is accomplished by gradually disappeared. A reality is reversed by the magic trick of the myth, history disappears and the natures come and sit down. As a result, the function of a myth is to make a reality disappears. This is a literally outflow, hemorrhage and evaporation. In short, it is a detectable absence"

Based on that, it can be said that readers will see that the myth here is not a myth like Sangkuriang. However, this is a kind of sign concept. In this study, the word jamu was considered a linguistic sign, which turned into a myth, obtained from the picture. On the other hand, based on Champion \& Furnham (1999), by saying "Jamu nee mas", these words turn into a sign, which means not a physical part, but it is a psychological part. The reason for placing it as a marker, because the seller seems to offer jamu only for men. Instead, herbs are a type of medicine, can be taken by men or women. Researchers see that this problem has a deep relationship with gender image.

From Barthes's explanation, one can see, that the marker, which has been typed, by still signifying the same can bring different connotations. Therefore, by examining this, researchers have found the ideology behind, as a gender ideology. By saying, "Jamu ne mas ..." the producer indirectly created a gender image for Indonesian women. Conversely, gender imagery always places them to be subordinates, creating stereotypes for jamu sellers. This is very much related to Barthes's implication (Barthes, 1979, p. 94), that "the role of the media is to instill the conformity of conformist morality in women, to tighten a little more securely in constitutive dogma of society."

Speaking of gender stereotypes, researchers will try to connect it, adding feminist theory to semiology theory. In this section, the researchers will examine the clothing worn by the Setan Jати Gendong. In semiology, things that can be examined are not only words or sentiments, but also one's abilities, by looking at the picture. Instead, the media can provide a myth analysis, which consists of a form of feminist problems. By looking at the clothing worn by herbal medicine sellers, it can be analyzed from a feminist point of view, that myth serves to strengthen and circulate highly patriarchal

\footnotetext{
*Author(s) Correspondence:

E-mail:mrs.astriindriana@gmail.com,oleel27@gmail.com
} 
sexual thoughts, disrupting women's ability to control their sexuality. This is related to what Champion \& Furnham (1999) explained that "people see the picture depicted and make a comparison with the idealized image" of jamu gendong seller in research on how teenage girls negotiate the meaning of being a woman.

By looking through kebaya, worn by Sri (herbal medicine seller), it can be said, that it is a kind of symbolic code. Linking to signified theory and signifier, we have said that it is used to reject and interpret something with a sign. Kebaya is considered a sign. The markers are traditional Indonesian clothing. In semiology, kebaya can be interpreted as subordination of Indonesian women by looking at how tight it is. Maybe it can be explained that by using kebaya, women cannot freely move their bodies.

Therefore, by seeing the kebaya, it might be considered as signifier. The kebaya worn by jamu seller generally creates inferior position in the movie. In addition, though the world will remain even, without providing sexist, the movie has opened new key for people to see and believe what they see in reality about women's position. By seeing this movie, the character of the jamu seller allows people to see gender stereotypes. It means whether dresses or the way of speech constitutes of cultural artefacts can communicate the problems behind.

The sexuality of jamu gendong sellers is used to encourage consumption, both for women and men. Roles refer to women and messages they try to give and create images in their appearance, that they show their identity to individuals. These roles may appear in business life, with diverse modernization. Women's sexuality is provided by almost every Indonesian film. The women appear, that they have been created as sexual objects, which provide themselves with films and are found attractive by men. All of the above explanations, the researchers tried to make semiotic tables, therefore readers or researchers could then see the relationship between semiotics and feminism.

\begin{tabular}{|c|c|c|}
\hline SIGN & SIGNIFIER & SIGNIFIED \\
\hline Human & $\begin{array}{l}\text { Woman Self- } \\
\text { Confidence }\end{array}$ & Youth and Sexy \\
\hline Object & Kebaya & $\begin{array}{l}\text { Indonesian } \\
\text { Traditional Clothes }\end{array}$ \\
\hline Object & Bakul & $\begin{array}{l}\text { Strong and } \\
\text { Independent }\end{array}$ \\
\hline Object & $\begin{array}{l}\text { The sound } \\
\text { "Jamune Mas" }\end{array}$ & $\begin{array}{l}\text { Jamu is medicine } \\
\text { just for men }\end{array}$ \\
\hline
\end{tabular}

From the perspective, comes from the table, the problem with the classic humanities has been a resolute rejection of any women methods. In cultural study, women are limited, and at worse as phenomenon distorting. In the Setan Jamu Gendong film, the clothes of women are designed to her body, measures and requests with the measure, and it is mentioned that jamu product is made for the seller. Due to all above, it could be told that sexuality has deep relation in conceptualizing, changing and developing world, and it is expressed in a satisfying ways and a reflection of it is seen in the film. Using women as a sexual object in many Indonesian movies is considered as normal thing although in our societies, talking about sex is forbidden and taboo. Considering that it would be seen that women are used in Indonesian movies are depicted as a strategy of marketing.

Entering woman position case, most audience would think that the jamu seller could defeat all men by using her sexy body and sexy voice. This case could consider that the producer seems placed her to be the subject of the text (film). Nevertheless, in the middle of film, the jamu seller was raped and killed by several men, so the woman position could consider as back to normal (as the object). By seeing that, the researchers see, like Kristeva (1986) called as Thetic Signification; "[Thetic] signification is a stage attained under certain precise conditions during the signifying process, and [...] it constitutes the subject without being reduced to his process precisely because it is the threshold of language."

\footnotetext{
*Author(s) Correspondence:

E-mail:mrs.astriindriana@gmail.com,oleel27@gmail.com
} 
Based on her explanation the researches would like to show that the words "Jamu ne Mas.." during the signifying process might change from the sexual subject, who could make any men get interested in her, into the sexual object, by seeing her body language that has placed her to be the object. Indeed, there are specific significant distinctions between women's and men's way of speaking. These are shown in thematic, lexical and grammatical features in speech. Women are usually more likely to court admiration about herself. It means that what she says or she acts are aimed to show how beautiful or how great they are. Finally, the researchers would like to say that, film is a kind of picture of the real life. Therefore, it can be analyzed, by comparing two women subjectivity in Indonesian films and their real life.

Talking about women's subjectivity, by connecting Kristeva's theory, it can be told that the particular attention to matters of Indonesia female subjectivity should be noted. By learning the theories, both Kristeva and Barthes, women subjectivity can conclude their psychological process to be the first gender. The researchers has related between Setan Jamu Gendong with Kristeva's theory because her theory is not associated with women's body. She never appreciates to women body, but she concerns about women's subjectivity. In this case, jamu gendong seller has used her body to create her subjectivity. Relating to Kristeva's theory, the words "Jamu ne mas.. jamu" uttered using the sexy voice, Kristeva argued it is considered as the issue of identity construction through language. The voice of the jamu gendong seller is defined as a kind of signifying process.

Those explanation is clearly explained in McAfee (2004) that "by the term signifying process, Kristeva means the various ways of expressing the bodily drives and energy through the use of language and how this process of signification constitutes the subjectivity of the speaking being"

By seeing the statements, the researchers would depict that jamu gendong seller in the beginning might create her body as a form to show her power and authority. It is related to what Kristeva stated in these second chapter of this research: "The realization of the separation of self and world is what produces language."

\section{CONCLUSION}

After researching Setan Jamu Gendong movie, the researchers could bravely show about the feminine gesture in Indonesian horror movie. In all representation of Indonesian female ghost, body's elements play an important role. It is not a coincidence that in Indonesian horror stories, the figure of sexy women like jamu seller (Sri) in this film always comes from the past. In the Indonesian horror films, the ghosts walk through historical walls, to show the audience, who live in the present, that there is a traumatic story behind her ghost appearance, Instead, whether in Indonesian horror movie or not, women are represented as vulnerable, naïve and powerless, or as distress hypersexual, including jamu seller (Sri).

By using semiotic, combining gender theories, the researchers have found that in this movie, the script writer seems would like to change the women common role. Nevertheless, in the middle of the film, the script writer sends back the woman's main character role into the miserable object. In the beginning, from the words which come out from the jamu seller, the researchers found her as the subject of the text, by seeing "Jamu ne.. mas.. jamu." The researchers place these words as signifier, because it considers as a kind of sign, that she can control all men, by her body and voice. Nevertheless, in the middle, by being the rape victims, the "clue" was failed.

Moreover, the researchers see that using her sexy body and voice, has made her identity draws the symbolic articulation. Her words, "Jamu nee mas", is such a picture that she insists on the reality of the bodily drives. In fact, actually, her assistance can not be shown in the symbolic. Instead, her act has manifested her self, in a structure of bodily

\footnotetext{
*Author(s) Correspondence:

E-mail:mrs.astriindriana@gmail.com,oleel27@gmail.com
} 
expression, that has disrupted the discourse among people.

Besides the whole things above, the researchers find that, in Kristeva's eyes and/or many feminist thought, that every woman seems to abject their body by having maternal body. Nevertheless, in this film, jamu gendong sellers seems to pleasurably use her body to attract people attention, especially men. She is able to sexually move her body, and that can make many men stare at her. This part of jamu gendong seller story, shown like a kind of refusing of Kristeva's statements, written in Pauline Keena's (2011) book about women abjection, who said: "By this I mean the process by which the mottled color became established on the canvas in the work practice and the relationship between that and the concept of abjection at both the physical and conceptual levels. By looking at the structures and regimes of practice within the research process I trace effective parallels between the art practice and Kristeva's theory of abjection"

Indeed, in order to describe the sexual imbalance, pleasure has been split between male as the active party and female as a passive party. The determining male gaze projects its phantasy on to the female body that is structured. In those men's traditional exhibitionist role, women are simultaneously seen and widely provided, using their appearance coded for strong visual and erotic impact. Setan Jamu Gendong movie seems to suggest that the image of subordination gender myths is mostly created. They are considered as a creature, who can make pleasure. Gender is generally inferior position in the movie.

\section{REFERENCES}

Barthes, R. (1967). Elements of Semiology. 1964. Trans. Annette Lavers \& Colin Smith. New York: Hill and Wang.

Barthes, R. (1972). Mythologies. 1957. Trans. Annette Lavers. New York: Hill and Wang.

Barthes, R. (1979). The Eiffel Tower, and other mythologies. Trans. Richard Howard. California: University of California Press.

Champion, H., \& Furnham, A. (1999). The effect of the media on body satisfaction in adolescent girls. European Eating Disorders Review: The Professional Journal of the Eating Disorders Association, 7(3), 213-228.

Dallery, A. B. (1989). The politics of writing (the) body: Ecriture feminine. Gender/body/knowledge:

Feminist reconstructions of being and knowing, 52-67.

Given, L. M. (Ed.). (2008). The Sage encyclopedia of qualitative research methods. London: Sage Publications.

Keena, P. (2011). An Investigation of the body as location in the context of Kristeva's reading of the maternal orientation of the abject (master's dissertation). Dublin Institute of Philosophy, Dublin, Ireland.

Kristeva, J. (1986). Revolution in poetic language. In T. Moi (Ed.), The Kristeva Reader. New York: Columbia University Press.

McAfee, N. (2004). Julia Kristeva. New York: Routledge.

Pagayo, K. (Director). (2009). Setan Jamu Gendong. Indonesia: Indika Entertainment.

Zaimar, O. (2008). Semiotik dan penerapannya dalam karya sastra. Jakarta: Pusat Bahasa Departemen Pendidikan.

*Author(s) Correspondence:

E-mail:mrs.astriindriana@gmail.com,oleel27@gmail.com 